\title{
Geographical and Demographic Approaches to Leaving Religion
}

\author{
Lily Kong and Orlando Woods
}

\section{1 \\ Introducing Geographical and Demographic Approaches to Leaving Religion}

This chapter provides an overview of geographical and demographic approaches to leaving religion. Just as the study of leaving religion is associated with processes of religious conversion and change, geographical and demographic approaches seek to map such changes across space and the human lifecycle. More than that, the fact that "people enter, exit, and move within religion, just as they are born, will die, and migrate, in life" (Voas 2003: 94) reveals the importance of such approaches, not least because they seek to understand religious change within the frame of life events, such as schooling, work, marriage, migration, procreation, upward (or downward) socio-economic mobility, retirement and death. By combining an understanding of demographic events and the socio-economic, political and cultural contexts within which religious change takes place, it will become apparent how geographical and demographic approaches to leaving religion are mutually enriching, and have the potential to offer unique perspectives to understanding the phenomenon of leaving religion.

To talk about leaving religion is, first and foremost, to accept that an individual identifies with a religion - one that is distinguishable from other systems of belief (Ivakhiv 2006). Leaving religion-or apostasy-is one half of the conversion equation; the other being the entering of religion. It should not be assumed that "leaving" religion is the same as "renouncing" religion; the process can be one of religious transfer as much as it is rejection. When viewing the process from a temporal perspective, the equation can be solved instantly (that is, when converting out of one religion and into another), protractedly (that is, when there is a period of time before converting into another religion) or never (that is, when the convert remains "religion-less") (see Streib 2012 for a broader overview of deconversion pathways). Further complicating the discourse are three necessary considerations. The first pertains to how actively an individual engages with their religion. Given that many individuals are born into the religious identity of their parents, the religion that they identify with 
is often not so much a function of their own choice (or an expression of their own religious agency), but of their circumstances and environments. In such cases, one may be nominally religious, but have little active engagement with the religion or belief in its doctrine; a case of "belonging without believing" (McIntosh 2015; after Davie's 1990 notion of "believing without belonging" and Day's 2011 notion of "believing in belonging"). If this is the case, then the notion of leaving the religion of birth becomes normative: it was not chosen, therefore leaving it is an expression of human agency overcoming the situational or circumstantial determinants of religious "choice." Moreover, recent debates concerning religious socialisation highlight the extent to which a religious upbringing can influence the decision to stay with or leave religion in later life (see Altemeyer and Hunsberger 1997; Loveland 2003).

Related to this is the second consideration, which pertains to the role of choice in the process of leaving. To leave a religion assumes a modernist distinction between being "in" or "out" of a religion; it is choice that dictates which side of the dualism one identifies with. Such a dualism is, however, fallacious in many contexts around the world. Indeed, the very idea of religious dualism (and its more integrative counterpart - religious syncretism) suggests that individuals can identify with more than one religion at once, and do not necessarily need to leave or be "out" of a religion in order to identify with a new one. Woods (2013), for example, highlights the retention of Hinduism amongst Christian "converts" in Sri Lanka, whilst Keyes (1993) shows how the spread of Buddhism amongst hill tribes in northern Thailand did not result in the replacement of one set of beliefs with another, but an expansion of understanding and the co-existence of multiple belief systems.

The third consideration pertains to classifications of "religion." If religion is a set of beliefs that are identified with or adhered to (or are just immanent), then can positions of secularism, atheism and agnosticism be classified as religions? If so, can converting from a position of secularity to one that identifies with a more formal religion such as Buddhism or Christianity constitute leaving one religion and entering another? Whilst we return to the problem of discursive framing later in the chapter, it is necessary to recognise upfront that we treat the field of "leaving religion" in a broad sense, to include both the transference and renunciation of "religion," and shifts from positions of "nonreligion" to "religion" as well.

Traditional geographical and demographic approaches to leaving religion concern the mapping of patterns of religion identification across space and 
the human lifecycle. Often, such mapping occurs periodically, with longitudinal analysis used to identify and explain changes in religion over time (see Zelinsky 1961; Park 1994). There are, however, some key differences between demographic and geographical approaches. Demographic approaches seek to correlate life events (such as getting married and having children), human development (such as rising incomes and access to education, and the associated propensity to migrate) and broader population profiling (such as changing gender and age profiles) with the act of leaving religion. This has involved studying how demographic variables such as gender, inter-religious marriage, socio-economic status and migration can affect the propensity to leave religion (see, for example, Hout et al. 2001; Lawton and Bures 2001; Kaufmann et al. 2012). Such studies strive to model behaviours and predict changes in religious composition over time. By correlating gender with leaving religion, for example, Skirbekk et al. (2010: 300) predict that men are six percent more likely to switch out of their religion of birth than women, and that women who identified with no religion at the age of 16 are twenty nine percent more likely than males to subsequently adopt a religion (a possible function of patriarchy within inter-religious marriage). Demographic modelling like this is predictive in nature, and aims to develop a macro-level overview of when - but not necessarily why - individuals are likely to leave a religion.

Geographical approaches have traditionally sought to explain the variability of religion across space (see Kong and Woods 2016). In doing so, they seek to highlight contextual differences that can explain why individuals may leave a religion. Geographical approaches have, therefore, the potential to sensitise the discourse to different interpretations of "religion," and what it could mean to "leave" it. Throughout history, geographical processes associated with the movement and diffusion of people, ideas and capital have resulted in largescale shifts in religious affiliation. Specifically, processes of modernisation (along with colonialism and the colonisation of territory, and international migration), communism and secularisation have all caused individuals to leave religion, and have therefore helped to reshape the religious topography of the world. Each of these constitutes a turning point impacting the religious lives of large populations. We examine each in turn below.

First, the modernisation of society and culture has caused populations to leave traditional religions associated with superstition and ritual. Whilst modernisation was once associated with colonialism and/or the colonisation of space by religiously-motivated groups, it has more recently found meaning in socio-economic advancement. In the first instance, colonialism caused the importation of religion to pre-modern societies, and introduced "the notion of religion as an individual option" (Ivakhiv 2006: 172, original emphasis; see also Smith 1998). Specifically, the missionisation of large parts of Asia, Africa 
and Latin America during the era of European colonialism resulted in departures from indigenous religions, and the uptake of Christianity (van der Veer 1996; see also Carlson's 2015 discussion of the Islamisation of the Middle East). This has, for example, transformed the religious topographies of the Philippines and Jamaica: from animism and $z e m i^{1}$ worship, to Catholicism and Protestantism respectively. In the second instance, in countries such as Singapore, socio-economic advancement has been shown to correlate with a shift towards more rational thought, which in turn has resulted in individuals leaving superstition-based systems of belief and embracing more cognitive, scripturebased religions such as Christianity, Islam and Buddhism (Tong 2007; Woods 2012a). Thus, whilst modernisation was once associated with the importation of religion by colonising powers, it is now associated with a more protracted shift away from superstition and ritual, and the uptake of more formal, "world" religions instead.

Second, the spread of communism throughout parts of Asia, Russia, Eastern Europe and Latin America from the 196os to 1980 s coincided with the spread of state-sponsored atheism. This was a response to the belief that organised religion contradicted the Marxist philosophy of communism, and must therefore be repressed. In Cambodia, the spread of communism under the Khmer Rouge (1975-1979) resulted in a departure from Theravada Buddhism, as witnessed by the forcible de-robing and execution of monks, and the destruction of temples and pagodas (Poethig 2002). Whilst expansive in scale and scope, the efficacy of such repression did, however, vary. In China, attempts to eradicate Christianity during the Maoist era (1949-1979) were largely unsuccessful, as Christians escaped execution and imprisonment by operating underground instead (Chao and Chong 1997). This demonstrates the geopolitical potential for scaling-up the analytical framework, showing how the state can influence religious change by actively (and sometimes forcibly) inducing a departure from religion.

Third, socio-economic advancement has witnessed the large-scale retreat of religion from many Western societies; a shift enshrined in the secularisation thesis. The secularisation thesis predicts that higher per capita income correlates with a lower demand for religion, as measured by regular participation in formal religious services and practices (Norris and Inglehart 2004). Such diminished demand is caused by the structural and social differentiation brought about by modernisation, which has caused the social role of religion to be eclipsed and replaced by other providers (Bruce 2002). Secularisation is believed to have caused Switzerland's Christian community to shrink from

1 A zemi is an ancestral spirit worshipped by the indigenous Taíno people of the Caribbean. 
ninety five percent of the population in 1970 to seventy five percent in 2000, and is projected to fall to forty two to sixty three percent by 2050. Similarly, Austria's Catholic community is predicted to shrink from seventy five percent of the population in 2001, to less than half by 2050 (Goujon et al. 2007). At a global level, the Pew Research Center (2015) predicts that during the period 2010-2050, the population of the religiously "unaffiliated" will grow by more than sixty million, with much of this growth coming from Christians converting out of religion and into a position of non-religion. Whilst such patterns have been witnessed throughout much of Western Europe, critical scholarship has more recently sought to interrogate the extent to which secularisation actually brought about a departure from religion, and whether or not such a process has now given way to an era of "post-secularisation" (Kong 2010), or a more nuanced understanding of contemporary religiosity that finds meaning in alternative forms of belief and spirituality.

In recent decades, traditional approaches have given way to more granular exploration of what it means to leave a religion. These new approaches reflect a change in focus: from identifying patterns, to exploring the processes and politics associated with leaving religion. This has also resulted in closer engagement with geographical conceptions of space, with the role of space shifting from that of a contextual canvas upon which religion is practiced, to a mediator and outcome of religious activity. This change in focus does, to a large extent, reflect the paradigm shift in cultural geography that occurred in the late 1980s; a shift that was informed by poststructuralist thought and the emergence of the geographies of religion as an increasingly viable subdiscipline withinhumangeography (seeKong 2001, Kong 2010; Knott2005; Dwyer 2016). Complementing such a shift has been the emergence of more complex and variegated religious landscapes brought about by international migration, which itself has contributed significantly to the processes of religious switching (through, for example, the shift from a majority to minority religious position during the migration journey). Thus, if traditional approaches sought to identify large-scale patterns of religious change, new approaches add nuance by exploring the effects of inter-community mixing and ever-greater religious pluralism on the propensity to leave religion.

Inter-religious mixing and pluralism has resulted in more complex webs of conversion practices and politics. Migrants' religious identities are often buttressed by specific ethnic and linguistic identities, creating rigid assemblages that, if left (or joined), can affect the convert in both positive and negative ways. On the one hand, Özyürek (2009: 102) draws on Viswanathan's (1998: xi) observation that "conversion is arguably one of the most unsettling political events in the life of a society" to show how German Muslims (who left Christianity) 
and Turkish Christians (who left Islam) are each depicted as threats to national security, and a "challenge to [the] socio-spatial ordering of self and other." Similarly, Ramahi and Suleiman (2017) coin the term "intimate strangers" to reflect the tension between estrangement and emotion experienced by female converts to Islam in the United Kingdom.

On the other hand, Kalir (2009: 132) demonstrates how the conversion of secular Chinese migrant workers to Christianity whilst in Israel is "because of a more deep-seated disposition towards what they consider to be a modern reformation of their personal identity." Converting to Christianity represents not just a departure from their secular past, but is also a metaphor for becoming "modernised." It involves leaving their (traditional, rural, impoverished) backgrounds behind, and embracing a Western belief system (that goes beyond Christianity) instead. The resultant cultural capital associated with conversion enables them to "symbolically distinguish themselves from nonmigrants" (Kalir 2009: 146), thus enforcing a sense of their own difference and, implicitly, betterment.

Demographical approaches to the study of leaving religion reflect - almost exclusively - a quantitative bias. The use of large-scale datasets is needed to provide the robustness needed to model population-related behaviours at the national level. Recently, such approaches have been refined by the use of timeseries data to offer longitudinal perspectives on leaving religion and religious change, and a shift from bivariate to multivariate modelling of religious behaviours (Sherkat 2001, Sherkat 2004; Kaufmann 2008). Combined, these developments have improved the sophistication of demographic analyses. This has resulted in the ability to more accurately model the net impact of secularisation by balancing net departures from religion with the net arrivals generated by immigration. Such modelling reveals the "power of demography to reverse secularization" which in turn "may lead us to question the widely shared view that secularization is an inevitable handmaiden of the modernization process" (Skirbekk et al. 2010: 304). Whilst such "powers of reversal" are transformative, they also highlight the potential for manipulation, and the whitewashing of statistical anomalies.

That said, as big data increases the range, quality and frequency of demographic data available to researchers, we can expect the predicting, inferencing and modelling of behaviour to become an increasingly integral part of the demographic value-proposition. Whilst the predictive focus is already evident 
in, for example, Skirbekk's et al. (2010) study of the religious composition of the United States until 2043, we can expect to see such modelling scale up (by looking at regions and inter-country dynamics), across (by looking at countries beyond the United States and, more generally, the West) and down (by examining subnational fluctuations). Such models will continue to be based on demographic projections, although their accuracy and sophistication will only improve as more data points become available through digital technology, and the predictive power of computational algorithms increases.

Whilst the geographies of religion subdiscipline is growing in prominence within the wider geographical enterprise, it has so far failed to sufficiently integrate religious conversion and the processes of leaving religion into its canon (Woods 2012a). Doing so has caused distinctively geographical perspectives to either be lost, unrecognised, or claimed by neighbouring disciplines within the broader social sciences (see, for example, Williams 2005; also Knott 2005). Indeed, much of the empirical work discussed in this chapter does not come from geographers, but from sociologists, political scientists and scholars of religious and area studies instead. Thus, whilst Kaufmann (2008:2) laments the fact that "sociologists often overlook the role of demography" when explaining religious change, the greater irony is that geographers are yet to engage with the discourse in a meaningful way either.

Geographical perspectives are not, however, without value; in fact, the reverse is true. Given that religion is, by now, "everywhere" (Dwyer 2016: 758) in geographical scholarship, and that religion "varies from place to place, context to context" (Ivakhiv 2006: 170), research must continue to embrace more critical, geographically nuanced approaches that unravel what it means to enter, leave, return to, and be "with" or "without" religion (Tse 2014). Such approaches can help to shed light on the key shortcomings of existing scholarship, which tend to be context-specific and yet universalising in their gaze. Most work on secularisation, for example, focuses on European contexts, where state religions prevail, but is problematised when applied to the more open religious marketplace of the United States (see Kaufmann 2008). Geographical sensitivity is therefore needed to overcome the focus on the "normative" West, and to re-engage with non-Western, often postcolonial contexts.

Doing so will serve to reify the terminological complexity that is inherent to the study of (leaving) religion by showing how "the language of conversion has often failed to adopt perspectives that are broad or inclusive enough to cover 
the full gamut of conversion processes and outcomes" (Woods 2012a: 445). Indeed, a growing trend throughout the United States is to self-identify with being "spiritual rather than religious; or as polyconfessional, multireligious, nondenominational, or evolving; or as religious but of no single persuasion, and so on" (Ivakhiv 2006: 170); a trend that, as recognised at the beginning of this chapter, is normative in other parts of the world. By destabilising - or removing - the boundary between categories of religion and non-religion, the potential for a more inclusivist discourse opens up; one that is sensitive to the potentialities of postmodern thought, and which questions the very premise that one can ever "leave" a religion.

A more critical discourse also requires new methodological approaches to overcome the quantitative bias outlined above. The veracity of large-scale datasets has often been uncritically assumed, and has led to a tendency to create what Bruce (1999: 40) terms "theor[ies] of everything" that attempt to "explain religious change at the macrolevel, yet in doing so... risk overlooking market nuances at the microlevel" (Woods 2012b: 217). These theories run the danger of coming across as overly simplistic - and, in some cases, misleading - in their explanatory potential. Increasingly, and in accordance with an injection of geographical sensibility, research should embrace more explorative and, therefore, qualitative approaches to understanding religious behaviours, actions and outcomes. Doing so would reflect more a methodological expansion than replacement. Quantitative approaches will still be needed to meet the instrumentalist demands of public policy and planning, but we can also expect more balanced, mixed methodology approaches that yield more holistic understandings of what it means to "leave religion."

\section{5}

\section{Suggestions How to Do It}

Geographers have a lot more to offer in terms of reframing and expanding the discourse. Doing so will help to extend the "transgressive lens" of the geographies of religion, and thus help to develop a more encompassing discourse that explores how leaving a religion "goes beyond the reorientation of individual belief, and is instead a process of change that involves the (re)definition of self and other" (Woods 2012a: 452, 440; Kong 2001; Kong 2010). Such a discourse would recognise the fact that leaving religion represents a departure from a pre-existing state of being, and would seek to identify and understand the political and symbolic ramifications of leaving a religion. In particular, to help realise the uniqueness of geographical perspectives, we suggest that scholarship focuses more explicitly on exploring how these ramifications intersect with the mediating role of space. 
An immediate and specific area of investigation is the processes and politics of dispossession associated with the religious conversion of space (see Woods 2012a, Woods 2013). Such dispossession transcends the individual, and can occur at various scales of analysis, ranging from the conversion of religious territory to the conversion of religious buildings. For example, the forcible conversion of Palestinian (Islamic) territory to the Jewish settlement of Israel involved a massive restructuring of the population, the renaming of physical landmarks, and other efforts to create a "distinct Hebrew toponymy" (Azaryahu and Golan 2001: 180). Similarly, one outcome of secularisation has been the conversion of churches and other places of religion into alternative lifestyle spaces, such as bars, clubs and residential accommodation (see, for example, Woods 2018, Woods 2019). At each scale, geographers can contribute unique perspectives by examining the processes - and ensuing politics - needed to desacralise space, and to bring about a departure from the religion that they were previously associated with. Doing so would contribute to a more wide-ranging discourse that engages more closely with issues of geopolitical and policy-related concern.

\section{References}

Altemeyer, B. and Hunsberger, B. 1997. Amazing Conversions: Why Some Turn To Faith \& Others Abandon Religion. New York: Prometheus Books.

Azaryahu, M. and Golan, A. 2001. "(Re)Naming the landscape: the formation of the Hebrew map of Israel 1949-1960." Journal of Historical Geography. 27:2, 178-195.

Bruce, S. 1999. Choice and religion: A critique of rational choice theory. New York: Oxford University Press.

Bruce, S. 2002. God is Dead: Secularization in the West. Oxford: Blackwell.

Carlson, T.A. 2015. "Contours of Conversion: The Geography of Islamization in Syria, 6oo-1500." Journal of the American Oriental Society. 135:4, 791-816.

Chao, J. and Chong, R. 1997. A History of Christianity in Socialist China, 1949-1997. Taipei: China Ministries International Publishing.

Davie, G. 1990. "Believing without Belonging: Is This the Future of Religion in Britain?" Social Compass. 37:4, 455-469.

Day, A. 2011. Believing in Belonging: Belief and Social Identity in the Modern World. Oxford: Oxford University Press.

Dwyer, C. 2016. "Why does religion matter for cultural geographers?" Social \& Cultural Geography. 17:6, 758-762.

Goujon, A., Skirbekk, V. and Fliegenschnee, K. 2007. New times, old beliefs: Investigating the future of religions in Austria and Switzerland. Working session on demographic projections, proceedings - Bucharest, 10-12 October, Eurostat Methodologies and working papers, $355^{-} 370$. 
Hout, M., Greeley, A. and Wilde, M.J. 2001. "The Demographic Imperative in Religious Change in the United States." American Journal of Sociology. 107:2, 468-500.

Ivakhiv, A. 2006. “Toward a Geography of 'Religion': Mapping the Distribution of an Unstable Signifier." Annals of the Association of American Geographers. 96:1, 169-175.

Kalir, B. 2009. "Finding Jesus in the Holy Land and Taking Him to China: Chinese Temporary Migrant Workers in Israel Converting to Evangelical Christianity." Sociology of Religion. 70:2, 130-156.

Kaufmann, E. 2008. "Human Development and the Demography of Secularization in Global Perspective." Interdisciplinary Journal of Research on Religion. 4:1, 1-37.

Kaufmann, E., Goujon, A. and Skirbekk, V. 2012. "The End of Secularization in Europe?: A Socio-Demographic Perspective." Sociology of Religion. 73:1, 69-91.

Keyes, C. 1993. "Why are the Thai not Christians: Buddhist and Christian conversion in Thailand." In R. Hefner ed., Conversion to Christianity: Historical and Anthropological Perspectives on a Great Transformation. Berkeley, California: University of California Press, 259-284.

Kong, L. 2001. "Mapping 'new' geographies of religion: Politics and poetics in modernity." Progress in Human Geography. 25:2, 211-233.

Kong, L. 2010. "Global shifts, theoretical shifts: Changing geographies of religion." Progress in Human Geography. 35:2, 755-776.

Kong, L. and Woods, O. 2016. Religion and Space: Competition, Conflict and Violence in the Contemporary World. London: Bloomsbury Publishing.

Knott, K. 2005. The Location of Religion: A Spatial Analysis. Oakfield, CT: Equinox.

Lawton, L.E. and Bures, R. 2001. "Parental Divorce and the "Switching" of Religious Identity." Journal for the Scientific Study of Religion. 40:1, 99-111.

Loveland, M.T. 2003. "Religious Switching: Preference Development, Maintenance, and Change." Journal for the Scientific Study of Religion. 42:1, 147-157.

McIntosh, E. 2015. "Belonging without Believing: Church as Community in an Age of Digital Media." International Journal of Public Theology. 9:2, 131-155.

Norris, P. and Inglehart, R. 2004. Sacred and Secular: Religion and Politics Worldwide. Cambridge: Cambridge University Press.

Özyürek, E. 2009. "Convert Alert: German Muslims and Turkish Christians as Threats to Security in the New Europe." Comparative Studies in Society and History. 51:1, 91-116.

Park, C. 1994. Sacred worlds: an introduction to geography and religion. London and New York: Routledge.

Pew Research Center. 2015. "The Future of World Religions: Population Growth Projections, 2010-2050." At http://www.pewforum.org/2015/04/02/religious-projections -2010-2050/. Accessed 18/o9/2017.

Poethig, K. 2002. "Movable peace: engaging the transnational in Cambodia's Dhammayietra." Journal for the Scientific Study of Religion. 41:1, 19-28. 
Ramahi, D.A. and Suleiman, Y. 2017. "Intimate strangers: perspectives on female converts to Islam in Britain." Contemporary Islam. 11:1, 21-39.

Sherkat, D.E. 2001. "Tracking the restructuring of American religion: Religious affiliation and patterns of religious mobility, 1973-1998." Social Forces. 79:4, 1459-1493.

Sherkat, D.E. 2004. "Religious intermarriage in the United States: Trends, patterns and predictors." Social Science Research. 33:4, 6o6-625.

Skirbekk, V., Kaufmann E. and Goujon, A. 2010. "Secularism, Fundamentalism, or Catholicism? The Religious Composition of the United States to 2043." Journal for the Scientific Study of Religion. 49:2, 293-310.

Smith, J.Z. 1998. “Religion, religions, religious.” In M.C. Taylor, ed., Critical terms for religious studies. Chicago: University of Chicago Press, 269-284.

Streib, H. 2012. "Deconversion." In L.R. Rambo and C.E. Farhadian eds., Oxford Handbook on Religious Conversion. Oxford: Oxford University Press.

Tong, C.K. 2007. Rationalizing Religion: Religious Conversion, Revivalism and Competition in Singapore. Leiden: Brill.

Tse, J. 2014. "Grounded theologies: 'Religion' and the 'secular' in human geography." Progress in Human Geography. 38: 201-220.

van der Veer, P. 1996. Conversion to Modernities: The Globalization of Christianity. London: Routledge.

Viswanathan, G. 1998. Outside the Fold: Conversion, Modernity and Belief. Princeton: Princeton University Press.

Voas, D. 2003. "Intermarriage and the demography of secularization." British Journal of Sociology. 54:1, 83-108.

Williams, R. 2005. "Introduction to a Forum on Religion and Place." Journal for the Scientific Study of Religion. 44:3, 239-242.

Woods, O. 2012a. "The geographies of religious conversion." Progress in Human Geography. 36:4, 440-456.

Woods, O. 2012b. "Sri Lanka's Informal Religious Economy: Evangelical Competitiveness and Buddhist Hegemony in Perspective." Journal for the Scientific Study of Religion. 51:2, 203-219.

Woods, O. 2013. "Converting houses into churches: the mobility, fission, and sacred networks of evangelical house churches in Sri Lanka." Environment and Planning D. 31:6, 1062-1075.

Woods, O. 2018. "Spaces of the Religious Economy: Negotiating the Regulation of Religious Space in Singapore." Journal for the Scientific Study of Religion. 57:3, 531-546.

Woods, O. 2019. "Religious urbanism in Singapore: Competition, commercialism and compromise in the search for space." Social Compass. 66:1, 24-34.

Zelinsky, W. 1961. "An approach to the religious geography of the United States: patterns of church membership in 1952." Annals of the Association of American Geographers. 51:2, 139-193. 